\title{
Monetary Policy Neglect and the Great Inflation in Canada, Australia, and New Zealand*
}

\author{
Edward Nelson \\ Federal Reserve Bank of St. Louis
}

\begin{abstract}
This paper studies the Great Inflation in Canada, Australia, and New Zealand. Newspaper coverage and policymakers' statements are used to analyze the views on the inflation process that led to the 1970s macroeconomic policies, and the different movement in each country away from 1970s views. I argue that to understand the course of policy in each country, it is crucial to use the monetary policy neglect hypothesis, which claims that the Great Inflation occurred because policymakers delegated inflation control to nonmonetary devices. This hypothesis helps explain why, unlike Canada, Australia and New Zealand continued to suffer high inflation in the mid-1980s. The delayed disinflation in these countries reflected the continuing importance accorded to nonmonetary views of inflation.
\end{abstract}

JEL Codes: E31, E52, E58, E64

Christiano and Gust $(2000,21)$ observe that the Great Inflation of the 1970s took place in many countries and note the desirability of "understanding why it happened and what can be done to prevent

*I thank Jason Buol for research assistance; the editor; two anonymous referees; David Archer, Guy Debelle, and Özer Karagedikli for comments on an earlier draft; and Lurlene Campbell, Wayne Carter, Elizabeth Dooley, Deirdre Hanlon, David Laidler, D. D. McNicoll, Joanne Rusk, Katrina Stierholz, Sharon Saunders, Gábor Toth, James Twaddle, and the services of Business Advantage, Business Information Service, and ProSearch for help in obtaining archival material. The views expressed in this paper are those of the author and do not necessarily reflect official positions of the Federal Reserve Bank of St. Louis, the Federal Reserve System, or the Board of Governors. Author contact: Research Division, Federal Reserve Bank of St. Louis, 411 Locust Street, St. Louis, MO 63102, Tel: (314) 4448712 (e-mail: edward.nelson@stls.frb.org). 
it happening again." In practice, however, examination of the U.S. experience has dominated the literature on the Great Inflation. This paper instead looks at three other countries that experienced the Great Inflation: Canada, Australia, and New Zealand. The record of these countries has been useful in studying the international experience with inflation targeting (Bernanke et al. 1999; Debelle 1996) and earlier developments in these countries can be useful in discriminating between different explanations for the Great Inflation.

As discussed below, several different hypotheses have been advanced in the literature on the Great Inflation to explain the overexpansionary monetary policy of the 1970s. While differing in detail, most of the different explanations - such as those emphasizing inflation bias by policymakers (e.g., Ireland 1999) or attempts to exploit Phillips curve trade-offs (e.g., Sargent 1999) — take for granted that the monetary authorities understand that their own actions, by expanding or contracting aggregate demand, have a decisive effect on the inflation rate. By contrast, the prevalent features of policymakers' statements in the United States (Romer and Romer 2002; Nelson 2004) and the United Kingdom (Nelson and Nikolov 2004) are the use of special-factors or "cost-push" explanations of inflation behavior and the promotion of nonmonetary devices (such as wage and price controls) as the means of controlling inflation. In light of this, Nelson and Nikolov (2004) argue that the monetary policy neglect hypothesis explains the Great Inflation: policymakers had a misguided view of the nature of inflation, and the Great Inflation occurred because inflation control was delegated to instruments other than monetary policy.

This paper presents further evidence for the monetary policy neglect hypothesis by showing that it accounts for policy developments during the Great Inflation in Canada, Australia, and New Zealand. I examine policymakers' statements and the record of their actions during the Great Inflation to draw out their views on the forces driving inflation. For the United States, Romer and Romer (2002) obtained information of this kind from Federal Open Market Committee (FOMC) minutes. No strictly comparable material exists for the three countries studied here, largely because their central banks were not independent during the 1970s. Instead, I document policymakers' views by examining newspaper reports as well as speeches of senior government figures. In addition to supporting the neglect 
hypothesis, this material helps rule out several other hypotheses that have been advanced to explain the Great Inflation.

This paper proceeds as follows. Section 1 gives an overview of the Great Inflation in each country. Section 2 outlines the monetary policy neglect hypothesis and discusses several alternative hypotheses. Sections 3-5 examine the policy record during the Great Inflation in Canada, Australia, and New Zealand. Section 6 concludes.

\section{An Overview of the Great Inflation}

Figures 1-3 plot four-quarter consumer price index inflation for Canada, Australia, and New Zealand. The increase in Canada's inflation rate from its 1960 s values to its 1981 peak is interrupted by declines in 1970-71 and after 1975. Only the first of these declines,

Figure 1. Four-Quarter CPI Inflation: Canada

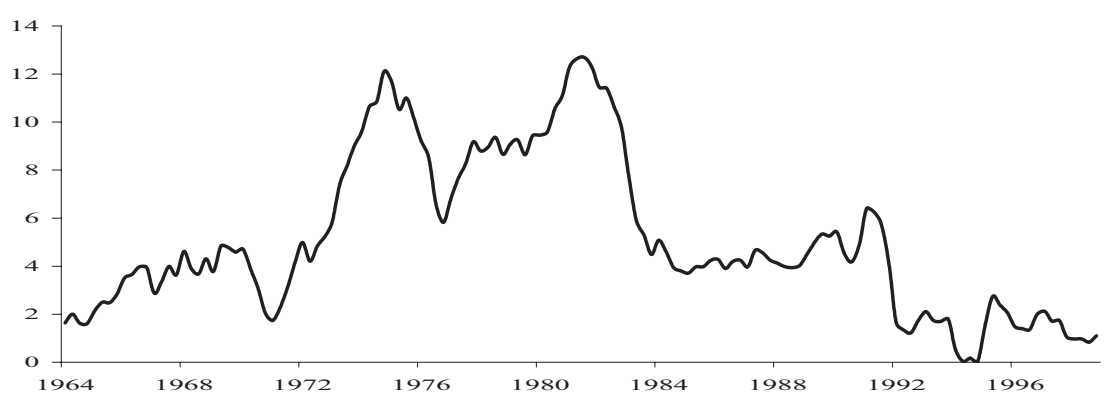

Figure 2. Four-Quarter CPI Inflation: Australia

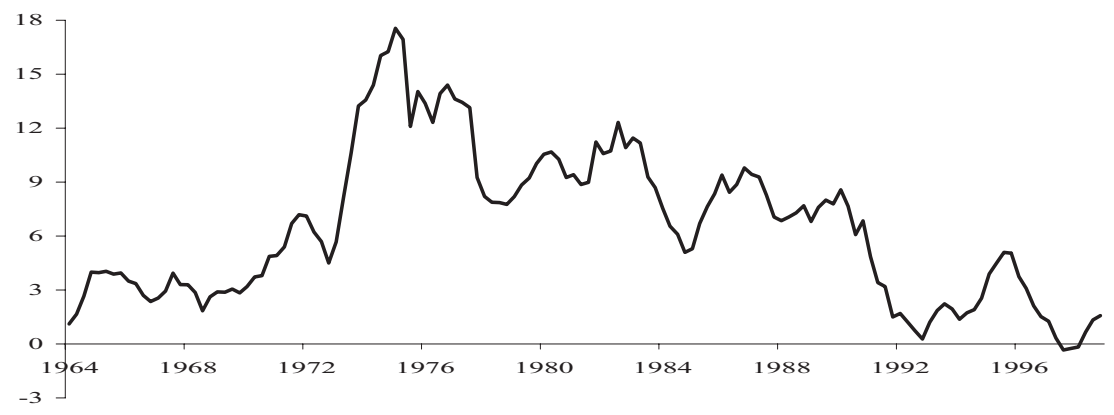


Figure 3. Four-Quarter CPI Inflation: New Zealand

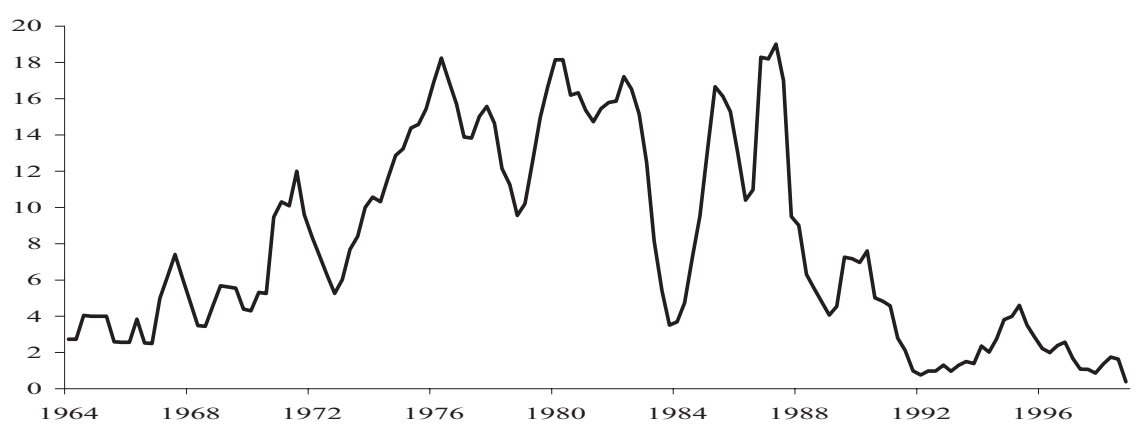

however, is genuine, as the second period was characterized by compulsory price controls (see section 3). Inflation shifts decisively to single digits in late 1982. Australia also has lower inflation in the 1980 s than the 1970s, but the improvement is marred by rebounds in 1985-86 and 1988-90, and in no quarter over 1973-90 does the rate fall below 5 percent. New Zealand inflation performance is poor in both the 1970s and 1980s; the temporary improvement in inflation over 1982-84 is wholly artificial, reflecting the imposition of a wage-price freeze over that period (see section 5 ).

Figures 4-6 compare actual short-term interest-rate choices with prescriptions for each year from a Taylor (1993) rule. ${ }^{1}$ In these charts, the target inflation rate is 2.5 percent and the steady-state real rate has been imposed at 4 percent (3 percent for Canada). These differ from the choice of 2 percent for both in Taylor (1993), but are justified by the different experience of these countries from the United States. The imposed 2.5 percent inflation target lies inside the target ranges currently being pursued in all three countries and, as discussed below, also corresponds to the concept of price stability prevailing among Australian and Canadian policymakers in the 1970s. Real interest rates in Australia and New Zealand have averaged above 3 percent under inflation targeting and have also tended to be higher than in the United States or Canada. This suggests that their average real rate compatible with price stability is at least

\footnotetext{
${ }^{1}$ The interest rate for Canada and Australia is the nominal Treasury bill rate; for New Zealand, it is the nominal short-term rate series of Orden and Fisher (1993).
} 
Figure 4. Short-Term Interest Rate and Taylor Rule Prescriptions: Canada

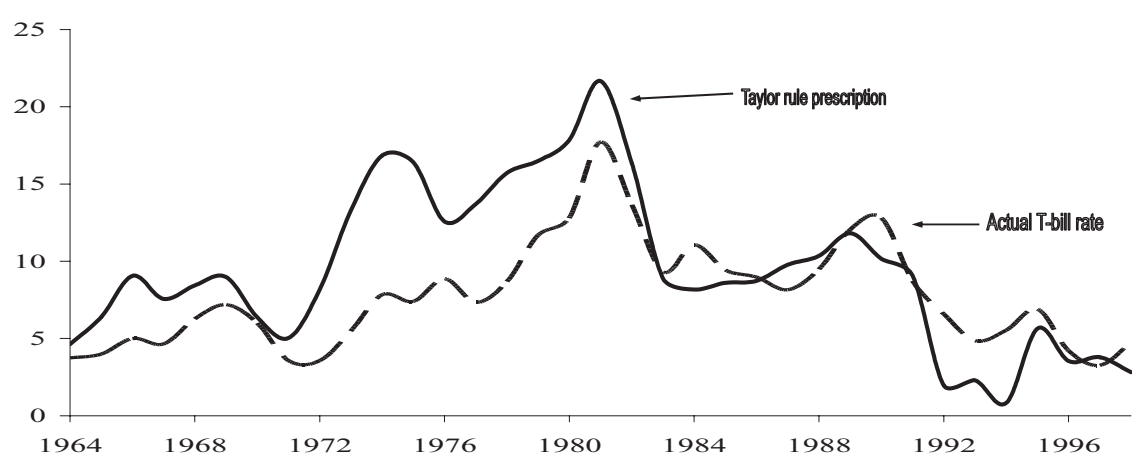

Figure 5. Short-Term Interest Rate and Taylor Rule Prescriptions: Australia

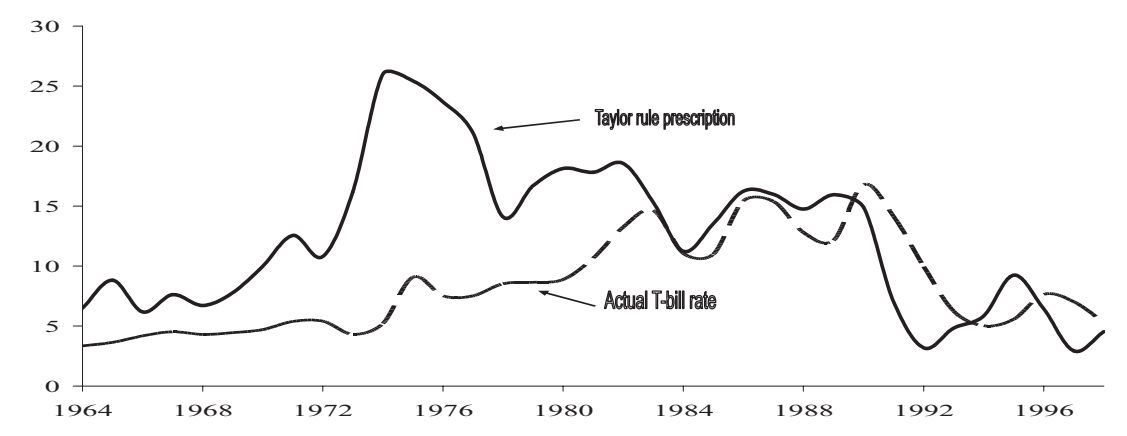

Figure 6. Short-Term Interest Rate and Taylor Rule Prescriptions: New Zealand

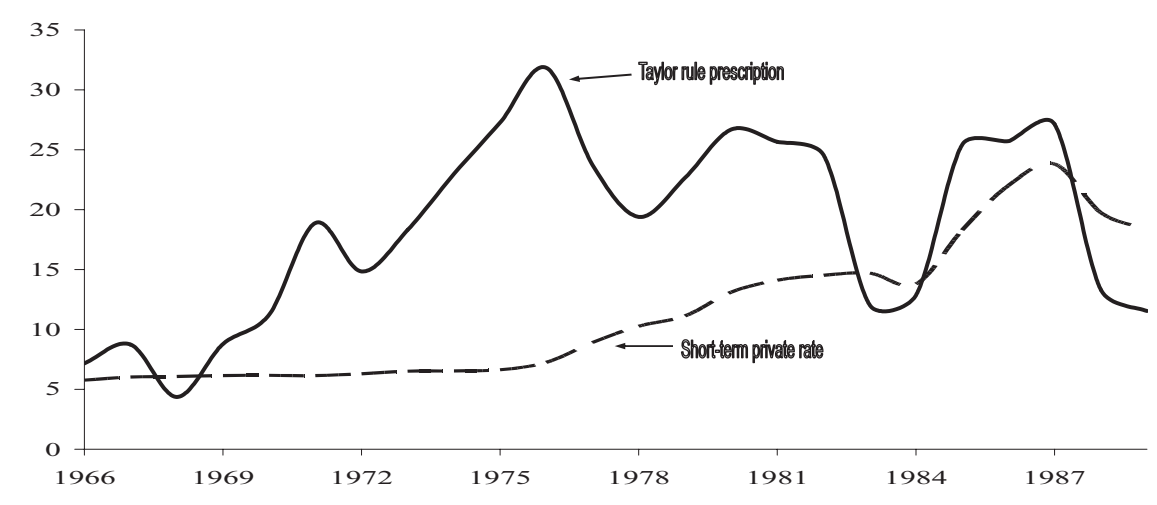


3 percent, while the global fall in real rates in the 1990s suggests that a still higher steady-state real rate should be assumed for the period studied here.

The Great Inflation in each country tends to correspond with large deviations from the Taylor rule prescription. One caveat is that the reliability of the rule prescriptions depends on the quality of the data used as inputs. Just as price controls in New Zealand artificially suppressed inflation over 1982-84, the use of the distorted inflation data in the Taylor rule produces a spurious dip in the interest-rate prescriptions.

A related caveat about data quality is that the rule prescriptions in figures 4-6 use detrended output computed from final data. As Orphanides (2003) shows for the United States, such revised estimates may differ substantially from policymakers' perception in real time of the position of output relative to potential. Figures 7-9 plot detrended output for the 1970s for each country, using final data, ${ }^{2}$ against estimates of the output gap during the 1970s. For Australia and Canada, historical estimates of the output gap were reported by the Organisation for Economic Co-Operation and Development (OECD) (1973). The 1977 Canadian output gap in figure 7 is an approximation of the series used in McCracken et al. (1977). ${ }^{3}$ For Australia and New Zealand, the 1977 gap is obtained by detrending the log of the $1977 I F S^{4}$ vintage of real gross domestic product (GDP) data, with the trend estimated on annual data for 1957-73.

\footnotetext{
${ }^{2}$ Final data on detrended output in figures 7-9 are linear-detrended annual GDP data, also used in figures 4-6. The linear trends assume breaks in 1974 (as well as 1995 for Canada and Australia). As figure 7 shows, for Canada, the resulting series has the implausible property of being negative virtually throughout the 1970s. An alternative (quadratic) detrending method instead yields a series that is positive throughout the 1970s. The high inflation and money growth outcomes in Canada suggest that the actual output gap was generally positive rather than negative.

${ }^{3}$ This approximation is obtained first by using the annual data on real GDP for Canada in IFS (June 1977). A potential GDP series for Canada, designed to match that used by McCracken et al., was then deduced from the information given in McCracken et al. (1977, 319) and Laidler (1978), i.e., 5 percent annual growth in potential output, and only one year (1973) in the 1970s during which output exceeded potential.

${ }^{4}$ Articles from newspapers and other periodicals are cited in the text by their acronym and date. Acronyms are given in appendix 1, while a bibliographical appendix (appendix 2) gives full details for each article.
} 
Figure 7. Output Gap Estimates: Canada

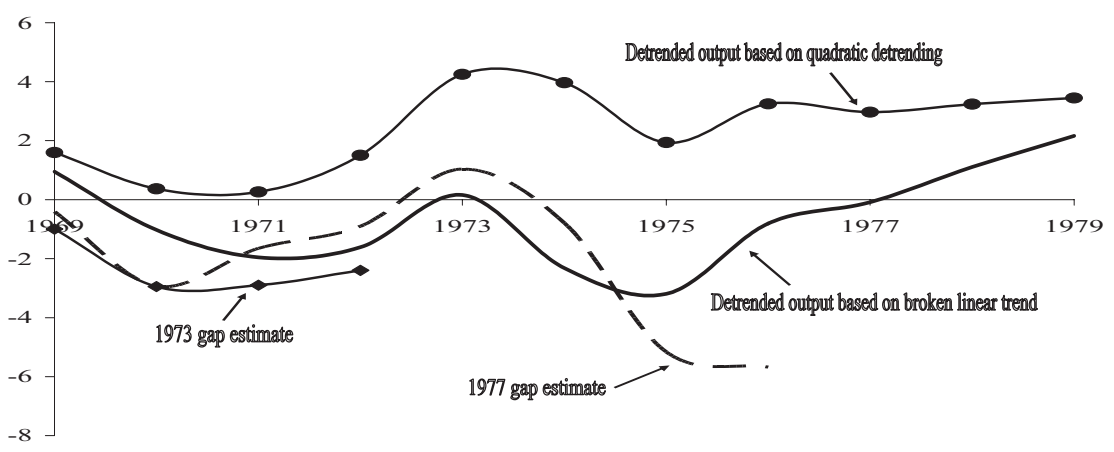

Figure 8. Output Gap Estimates: Australia

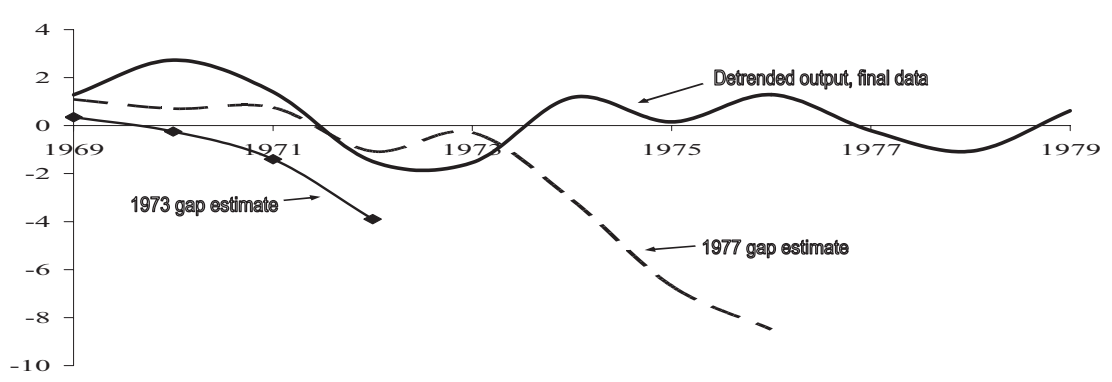

Figure 9. Output Gap Estimates: New Zealand

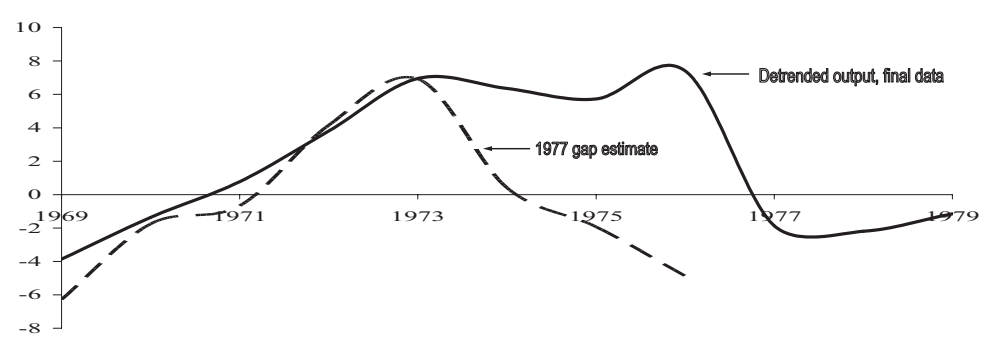


Table 1. Average Annual Output Growth Rates*

\begin{tabular}{|c|c|c|c|c|c|}
\hline \multicolumn{2}{|c|}{ Canada } & \multicolumn{2}{c|}{ Australia } & \multicolumn{2}{c|}{ New Zealand } \\
\hline $1962-1973$ & $1974-1993$ & $1961-1973$ & $1974-1993$ & $1961-1973$ & $1974-1993$ \\
\hline 5.3 & 2.7 & 4.8 & 2.8 & 4.9 & 1.0 \\
\hline
\end{tabular}

*For Canada and Australia, output is defined as real GDP; for New Zealand, output is defined as nominal GDP divided by the CPI.

This is intended as an approximation of how policymakers in 1977 estimated potential GDP. ${ }^{5}$

Comparison of these 1973 estimates with today's estimates of detrended output suggests that the initial numbers overstated the weakness of demand in the early 1970s. In addition, like the United States, the three countries studied here experienced slower growth in output after 1973 (table 1). The detrended output series plotted in figures 7-9 take this break in trend into account, but gap estimates up to 1977 did not. As a result, the 1977 gap estimates reported in figures 7-9 are far more negative in the late 1970s than the final estimates of output relative to trend. As we will see below, the nature of these errors did much to move policymakers away from orthodox approaches to analyzing inflation.

\section{The Monetary Policy Neglect Hypothesis}

Using the standard New Keynesian Phillips curve, the behavior of inflation may be written

$$
\pi_{t}=b_{1}+b_{2} \mathrm{E}_{t} \Sigma_{i}={ }_{0}{ }^{\infty} b_{3}{ }^{i}\left(y_{t+i}-y_{t+i} *\right)+b_{4}\left(u_{t}-\mathrm{E}\left[u_{t}\right]\right)
$$

where $\pi_{t}$ is inflation, $y_{t}$ is $\log$ output, $y_{t} *$ is $\log$ potential output, $u_{t}$ is an exogenous disturbance, and the $b_{i}$ are positive coefficients with $b_{3}$ near unity. As in Nelson (2004), the alternative views of inflation in 1970s debates - monetary versus nonmonetary - may be expressed as restrictions on equation (1).

A nonmonetary explanation of inflation attributes the 1970s inflation to persistent movements in the $u_{t}$ term in equation (1) - often

\footnotetext{
${ }^{5}$ The post-1973 slowdown in potential was not noted officially in New Zealand until 1978 (see section 5). Recognition was slow too in Australia, with Nevile's $(1981,50)$ assumed lower bound on post-1973 potential growth being 4.1 percent.
} 
termed "cost-push" fluctuations - as well as to shifts in the mean of the $u_{t}$ process (which thus produced shifts in the constant term, $b_{1}$ ). This explanation contends that excess demand did not matter for inflation, as it maintains that the coefficient $b_{2}$ goes to zero when the output gap $\left(y_{t}-y_{t}{ }^{*}\right)$ is negative. Therefore, according to this explanation, output falling below potential does not produce any downward pressure on inflation. Exponents of the nonmonetary explanation of inflation in the 1970s frequently conceded that a role for excess demand factors in driving inflation arises when output is above potential, ${ }^{6}$ but this was a minor qualification, as they believed that the output gap was rarely positive during the 1970s.

A monetary explanation of inflation, on the other hand, contends that $b_{2}$ is well above zero for all values of the output gap, and that the shifts in inflation during the 1970s are attributable to excessive aggregate demand (protracted periods of positive output gaps) created by the monetary authorities. The explanation concedes a role for the $u_{t}$ term in equation (1) in producing one-time movements in the price level, but not sustained movements in inflation. Together with $b_{2}>0$, the monetary explanation therefore imposes the restrictions that $y_{t}$ is interest-elastic (so excessive aggregate demand can be prevented by monetary policy), and that $u_{t}$ has a zero mean (implying that $\mathrm{E}\left[u_{t}\right]$ does not enter the expression for $b_{1}$ ) and is white noise (so only excess demand and the constant term enter the expression for expected future inflation). ${ }^{7}$

The monetary policy neglect hypothesis claims that the monetary explanation is the correct one, but that policymakers in the 1970s subscribed to the nonmonetary explanation. They therefore relied on wage and price controls, rather than monetary policy, to control inflation.

The hypothesis thus has two components: about inflation (the validity of the monetary view) and about policy behavior (the claim that policymakers embraced a nonmonetary view of inflation). In section 2.1 below, I consider the applicability of the monetary view of inflation to the three countries studied here. Before that, it is useful to discuss several alternative hypotheses about policy behavior in the Great Inflation and why they do not fit the facts for these countries.

\footnotetext{
${ }^{6}$ That is, they subscribed to an asymmetric version of (1), where $b_{2}$ turns positive only when the output gap is positive.

${ }^{7}$ The white-noise restriction additionally implies $b_{4}=1$ in equation (1).
} 


\subsection{Consciously Inflationary Policies}

One class of explanations for the Great Inflation attributes to policymakers a conscious choice of inflationary policies. For example, the time-consistency explanation, pursued for the 1970s inflation by Ireland (1999), postulates that policymakers had an objective of a positive output gap. While rejecting the time-consistency story, DeLong (1997) argues that political pressures made it necessary to set unemployment targets below the natural rate. But as we will see, policymakers in Canada, Australia, and New Zealand repeatedly stated their output goal as potential, not some level beyond their estimate of potential. This goal also featured in their internal discussions: for example, a Treasury submission to cabinet in Australia in 1973 stated that "the capacity of supply" should govern policy on demand management ( $A C R$, October 5, 1973).

Nor does these countries' experience suggest a conscious targeting of high inflation rates, either because of feared costs of low-inflation equilibria (as in Christiano and Gust 2000) or low estimates of the cost of high inflation. Inflation was regarded as costly - for example, Prime Minister Whitlam of Australia said in 1974, "Let me be frank: inflation costs jobs" (TA, October 22, 1974) - and the authorities' recourse to wage or price controls in each country was a drastic (though misguided) attempt to escape high inflation. The concept of price stability seems to have been similar to that in the later inflation targeting period: for example, Prime Minister Pierre Trudeau said in 1970 that "inflation no longer exists in Canada" when the fourquarter rate fell into the 2-3 percent range (TST, December 24, 1970), while the Australian Treasury in 1973 characterized the costs

of inflation as occurring when inflation rose above the 3 percent barrier $(A C R$, October 5, 1973).

\subsection{Convergence to a Vertical Phillips Curve Model}

Sargent (1999) characterizes policymakers as entering the Great Inflation with a nonvertical long-run Phillips curve model and as converging to a vertical model as they observed the stagflation of the 1970s. This account does not describe either the initial conditions or the learning process in the three countries studied here. As of 1970, none had a nonvertical Phillips curve guiding policy; 
rather, Canada's authorities actually subscribed to a long-run vertical Phillips curve, while the other two countries had a cost-push view of inflation. Moreover, in all three countries, the 1970s outcomes convinced the authorities of the validity of the cost-push view of inflation, rather than moving them to a more orthodox framework. The reason is that the Sargent story requires policymakers to observe that the output gap returns to zero despite larger doses of inflation, whereas 1970s policymakers thought they observed combinations of sustained high inflation and large negative output gaps. The costpush view of inflation was therefore appealing because it rationalized arbitrary inflation/output gap combinations. Consequently, support for the conventional approach to inflation collapsed in Canada, while in Australia and New Zealand, support for the cost-push view of inflation hardened. For example, Prime Minister Muldoon of New Zealand said in 1977, "In this economy, unemployment and inflation are not related; I'm convinced of that" ( $E P$, October 14, 1977), offering this as the basis for why his expansion of demand would not stimulate inflation, while former Prime Minister Whitlam of Australia said that inflation-control methods based on demand management didn't "cater for this new situation" where "there was both unemployment and inflation" (MES, January 6, 1977).

\subsection{Unfavorable Sacrifice Ratios}

Taylor (1997) suggests that 1970s policymakers understood that the Phillips curve was vertical in the long run but believed that the output-gap elasticity in the Phillips curve had diminished, so that an unfavorable sacrifice ratio discouraged policymakers from disinflating. According to this hypothesis, a disinflation via monetary restraint was regarded as too costly, whereas the neglect hypothesis instead says that policymakers believed that it was infeasible. As close as these hypotheses are, the neglect hypothesis is preferable, as it better rationalizes policymakers' views on both the effects of monetary restriction and on their menu of policy options.

The sacrifice-ratio story does not rationalize policymakers' actual views on the effects of monetary restriction because it attributes to them the understanding that as monetary policy is made progressively tighter, inflationary pressure is reduced-that is, that $b_{2}$ in equation (1) is low but strictly positive. By contrast, 1970s 
policymakers often subscribed to the view that tightening worsens inflation - either via an interest-cost-push channel or through a unitcost-push effect (i.e., the positive effect on unit costs of a reduction in aggregate demand and thus output). We will see that this view was influential in Canada in the lead-up to price controls in 1975 and was prominent in New Zealand and Australian public debate until 1984 and 1985, respectively. From a monetary perspective on inflation, this view is inappropriate because it emphasizes partial-equilibrium effects instead of the general-equilibrium effect (i.e., the dependence of total costs on excess demand). But from a pure cost-push perspective (i.e., $b_{2}=0$ in equation [1]), the view can be rationalized because the general-equilibrium effect is absent.

The sacrifice-ratio story also does not rationalize policymakers' accounts of their menu of choices during the Great Inflation. A low $b_{2}$ in the Phillips curve still leaves a continuous relationship between aggregate demand control and inflation, and so standard messages still hold: greater inflation control requires tighter monetary policy; direct wage and price controls merely suppress the symptoms of inflation. By contrast, policymakers in the Great Inflation felt that the cost-push nature of inflation gave them a "free lunch" whereby successful direct measures could eliminate the causes of inflation while leaving them to stimulate aggregate demand to eliminate the output gap. This free-lunch view not only guided policy during periods of mandatory wage and price controls in these countries, but also underpinned policymakers' support for wage/tax trade-offs. For example, New Zealand's Prime Minister Muldoon said in 1981, "The most important single action to reduce inflation would be a wage/tax tradeoff" (EP, November 4,1981), while Australian governments both in late 1974 and early 1988 advanced wage/tax trade-offs as means of breaking inflation, even though they had undertaken major easings of monetary policy. Because it posits the compatibility of monetary expansion and inflation reduction, this free-lunch aspect of policymakers' views is inconsistent with the sacrifice-ratio hypothesis, but is consistent with the neglect hypothesis's account of their views. ${ }^{8}$

\footnotetext{
${ }^{8}$ Note that the free-lunch view cannot be brought within the prism of the standard monetary view of inflation by interpreting it as support for measures to improve aggregate supply. Starting from a position of a negative output gap, a successful supply-side measure reduces inflation but worsens the output gap by adding to unused potential. Monetary expansion alongside the supply-side
} 


\subsection{Output Gap Misperceptions}

Orphanides (2003) attributes the Great Inflation to policymakers' responses to estimates of the output gap that overestimated the amount of slack in the economy. As figures 7-9 suggest, output gap misperceptions were certainly part of the experience of the three countries studied here. The hypothesis advanced in this paper instead takes issue with the position that output gap mismeasurement was the primary source of policy error. While Orphanides (2003) argues that actual monetary policy in the 1970s had a modern inflation-oriented outlook, the monetary policy neglect hypothesis argues that policymakers had an incorrect (nonmonetary) model of inflation, leading to an assignment of inflation control to nonmonetary devices. These conceptual errors were compounded by output gap mismeasurement which, by giving the appearance that negative gaps coexisted with high inflation, ratified the authorities' adherence to cost-push views of inflation. The discussion in sections 3-5 will identify specific episodes where misperceptions of the output gap and policymakers' cost-push inflation theories reinforced one another.

\subsection{The Nature of Inflation}

Since the monetary policy neglect hypothesis rests on the contention that the monetary view of inflation is valid, it is worthwhile to discuss the implications of this view of inflation and its applicability to the three countries studied here.

The above characterization of the monetary view of inflation as corresponding to $b_{2}>0$ with $u_{t}$ white noise means that price-level shocks can shift current inflation even without monetary accommodation, but cannot become entrenched in the expected inflation rate in the absence of accommodation. No matter how exogenous the shock to a specific price or wage, standard theory suggests that the response of aggregate prices over time will be endogenous: a sudden price movement may initially jolt the aggregate inflation rate

improvement involves sacrificing some of the improvement in inflation. In addition, the principal rationale for incomes policies (such as wage-price controls or wage/tax trade-offs) was that they directly removed cost-push pressures, not that they increased potential output. 
upward, but prices cannot continue to rise at the new higher rate if the monetary authority does not allow faster rates of growth of aggregate demand. For example, the effect of an oil shock on the expected future inflation rate can be neutralized if the authorities allow the path of real aggregate demand to match the new path of potential output. This framework can also accommodate the openness of the three economies studied here by treating imports as an intermediate good and thus mattering for potential output in the Phillips curve.

The wage-push view of inflation has sometimes been defended for Australia and New Zealand on the grounds that independent government bodies (arbitration courts) determined minimum wages and some aspects of the relative wage structure. This institutional feature does not overturn the monetary view of inflation in principle, because the courts' decisions directly affected current growth in a portion of wages in the economy, while in the optimizing analysis underlying (1), inflation depends on the whole expected path of marginal cost (see Woodford 2003), which will be endogenous even if some period- $t$ cost increases are exogenous. Moreover, arbitration court decisions in practice often ratified where market forces were pushing wages. For example, the mandated increases in wages in 1973-74, often cited as an exogenous event, occurred in the wake of a booming economy and extreme monetary expansion. Indeed, actual wage growth in 1973-74 in Australia exceeded the mandated growth rates by wide margins (Gruen, Pagan, and Thompson 1999, app. A). This period therefore fits into Bernanke's (2004) description of a case where "[s]eemingly unexplained or autonomous movements in wages and prices... may in fact have been the result of earlier monetary policy actions."

With this background to the monetary policy neglect hypothesis in mind, let us now consider in detail the record of each country during the Great Inflation, starting with Canada.

\section{Canada}

Canadian monetary policymakers ended the 1960s with a disinflationary strategy informed by several modern insights. Not only did they subscribe to a conventional view of the inflationary process, they recognized and explicitly endorsed the hypothesis that the 
long-run Phillips curve was vertical. Louis Rasminsky, the governor of the Bank of Canada, did so in early 1969 when he described the inflation/unemployment trade-off as "an illusion" because "people... develop an expectation of continuing inflation and adjust their behavior accordingly" ( TGM, February 21, 1969). In addition, Prime Minister Pierre Trudeau himself stated in 1970 that it had "been shown that this trade-off is a short-run phenomenon, and that sacrificing price stability will not by itself aid in improving a country's long-run employment situation" ( $C P D$, October 9, 1970, p. 33). The latter statement was especially notable because it came from the executive branch of government which, in Canada as well as the two other countries studied in this paper, had effective control over monetary policy throughout the 1970s.

By 1975, however, the Canadian authorities had moved from this conventional position to an adherence to a nonmonetary view of inflation, and imposed compulsory wage and price controls. The transition to this state of affairs is due to two factors. First, a strong body of opinion in Canada advocating cost-push positions existed from the beginning of the 1970s. Second, errors in official estimates of the output gap led to estimated gap/inflation combinations that were a challenge for the conventional theory of inflation to explain. Both these factors grew in importance over the period of conventional policy, 1969-71.

\subsection{9-71: Orthodox Beginnings}

Over 1969 and 1970, the Canadian authorities gave primacy to aggregate demand restraint in reducing inflation. Prime Minister Trudeau indicated that "our policies to slow down the economy... will be slackened when the inflationary psychology is broken in this country" ( $C P D$, April 17, 1970, p. 5984). Moreover, policymakers indicated that they would not be perturbed if the period of monetary restriction led to an interim period of simultaneous rising unemployment and continuing high inflation. Governor Rasminsky said that it would "not be too surprising, given the lags involved, if there is a temporary, rather discouraging period when we seem to be getting the worst of both worlds" (FP, November 1, 1969).

Several outside commentators resorted instead to cost-push explanations of Canada's macroeconomic behavior, most persistently 
the Toronto Star newspaper, both on its editorial page and through its economics columnist, Dian Cohen. Cohen's view was that it was "very hard to maintain that our current inflation is the result of excessive demand," and that the lesson from the U.S. experience for Canada was that monetary tightening "invariably resulted in massive unemployment without the desired price stabilization" (TST, February 2, 1970). Restrictive monetary policy worsened inflation in her analysis via the unit-cost-push effect; fiscal tightening could also be counterproductive because "as taxes go up so, ultimately, do prices" (TST, December 14, 1970). ${ }^{9}$ Cohen combined these positions with interest-push and wage-push views to conclude that "the chief sources of inflation are rising taxes, rising interest-rate costs, rising wages and salaries - and even rising unemployment" (TST, March 1, 1971) and that "economic policies that have traditionally been thought to curb inflation actually aggravate and encourage it" (TST, March 27, 1972). The Toronto Star editorials concurred that Canada's problem was "'cost-push' inflation [which] occurs when corporations and organized labor take out more than they're putting in" (TST, August 21, 1971) and advocated a wage-price freeze followed by a system of direct controls - which it called "the only weapon left against inflation" (TST, February 10, 1972).

The government was initially in a good position to resist these criticisms, as its restrictive policy brought inflation below 3 percent by the end of 1970 without resort to controls. However, as figure 7 shows, the government overestimated the amount of slack it had created in producing this favorable result. Consequently, it switched to a considerably easier policy in 1970. Even in late 1971, the OECD judged that "an expansionary economic policy still appears appropriate, given the existing amount of slack in the Canadian economy" (WFP, December 28, 1971). In fact, however, the government had already injected so much stimulus that inflation was on the way back up.

\footnotetext{
${ }^{9}$ Similarly, Don McGillivray in the Financial Times of Canada wrote that the "[e]vidence that taxes are a cause of inflation" was "piling up" (FTC, December 4, 1972), while Lubor Zink in the Toronto Sun asserted that "every increase in tax rates is soon reflected in higher production costs and consumer prices" (TSN, March 8, 1974).
} 


\subsection{2-74: Blaming International Factors}

The resurgence of inflation in 1972 converted the Canadian authorities to cost-push analysis and nonmonetary remedies. They would deny, in line with the output-gap estimates available at the time, that Canada had an excess-demand problem. Instead, they would blame international factors - what Prime Minister Trudeau called "worldwide economic pressures largely beyond our control" (TSN, March 6,1974 ) - for provoking inflation in Canada. According to this argument, the revival of inflation in Canada arose from its pressure on the prices of world commodities, due to excess demand outside Canada. Import-price inflation and cost-of-living adjustments of wages had then driven up CPI inflation within Canada. The policy response over 1972-74 consisted of actions to affect specific prices, as well as tax cuts. Monetary policy, on the other hand, was eased to fight the perceived unemployment problem.

Finance Minister Turner foreshadowed the government's reliance on commodity-price-push as the explanation for Canada's inflation when in early 1972 he noted that the country's inflation performance had recently deteriorated, but "this is partly attributable to special factors relating to food" ( $C P D$, February 24, 1972, p. 215). His diagnosis was similar two years later, when he contended that "the sharp increase in oil prices plus the rise in commodity and food prices constitutes the primary thrust of inflation in this country" ( $C P D$, January 7, 1974, p. 9100).

In September 1973, Turner listed the specific measures the government had taken against inflation: sales tax cuts, tariff reductions, and controls on the export of agricultural products $(C P D$, September 13, 1973, p. 6513). Similar measures were announced in his May 1974 budget. These actions were intended to offset the effects of world inflation on the CPI, by reducing the extent of the commodity price increase in Canada and by acting on the prices of other CPI components.

The government's acknowledgment of a contribution of developments within Canada to inflation was limited. Turner saw the problem as "a complicated interaction between world demand-pull inflationary forces and the reaction in Canada of cost-push forces," such as wage earners demanding compensation for price increases ( $C P D$, January 7,1974 , p. 9100). The authorities saw income tax cuts as 
the means of arresting spirals of this type, by increasing disposable income without wage increases ( $C P D$, February 19, 1973, p. 1435). Prime Minister Trudeau also indicated that the government would increase antitrust regulation to deal with "the cause of certain types of cost-push inflation... [W] e're dealing first with the monopoly of business because that is the more dangerous one" (TST, September 20, 1973).

To accompany these nonmonetary measures, Turner said that "monetary policy... [will] continue to be expansionary" ( $C P D$, April 10, 1973, p. 3132). In 1974, he rejected "deflation of demand by severe measures of fiscal and monetary restraint" as a solution to inflation (CPD, May 6, 1974, p. 2078) and instead described his strategy as "breaking the inflationary spiral without impeding the continued strong growth of production, employment and income" (TGM, June 8, 1974). Endorsing the unit-cost-push argument, he claimed that restrictive demand policies abroad were worsening inflation because they resulted in lower production ( $C P D$, October 9, 1974, p. 260).

The evidence in figure 4 suggests that, contrary to beliefs at the time, loose Canadian monetary policy was responsible for the return of inflation. As noted above, the easing had started with the expansionary measures of 1970. Neither excess demand abroad nor the rise in commodity prices actually provides grounds for believing that Canada could have sustained inflation without monetary stimulus. Canada's exchange rate had floated in 1970, providing the conditions under which international shocks should impact relative prices, but not the ongoing inflation rate, within Canada. The authorities did not take advantage of those conditions. Instead, their cost-push interpretation of inflation encouraged them to continue monetary expansion.

\subsection{4-75: Drift to Controls}

In late 1974 the government began to nominate wage-push as the source of inflation. In his November budget speech, Turner claimed that "the response to earlier international price increases has provoked domestic forces of cost-push inflation in Canada" ( $C P D$, November 18, 1974, p. 1421). Mechanically, the government's changed diagnosis arose from the fact that commodity price growth had receded, while double-digit CPI inflation continued. 
Inflation - according to the cost-push view - thus became "domestic" in character. A more standard analysis, however, would dispute that inflation's character had changed - rather, excessive demand conditions remained the problem throughout. These conditions account for why high inflation continued even after commodity price pressures eased.

The government responded by arranging talks on a voluntary incomes policy ( $C P D$, November 18, 1974, p. 1423). Following the collapse of these talks in May 1975, Prime Minister Trudeau said that the change in the character of inflation from international to wage-push meant that the case against compulsory wage and price controls had weakened (TST, May 23, 1975). On October 13, 1975, Trudeau announced a three-year control program.

\subsection{5-78: Monetary Policy in the Controls Period}

In conjunction with the imposition of the controls, Finance Minister Macdonald announced that the Bank of Canada would pursue targets for M1 growth, on the grounds that it was "essential for the success of any prices and incomes policy to avoid too rapid a rate of growth of demand and the development of excess pressure on resources" (TGM, October 15, 1975). The stage, therefore, seemed set for a restrictive monetary policy to accompany price controls, thus providing a counterexample to the generalization that periods of control are accompanied by monetary ease.

In practice, however, such a counterexample did not emerge: while policy did tighten over 1976, nominal interest rates fell and currency growth picked up during 1977. The M1 targets were met throughout, but hitting these targets did not restrain other measures of money growth or require increases in nominal interest rates, because households reduced their M1 holdings relative to other deposit categories. Consistent with the easing, inflation revived over 1978-81.

Much of the easing was conscious and reflected the lingering influence of cost-push views - i.e., that Canada's inflation was of a nonmonetary character and that, therefore, the case for restraining aggregate demand was not compelling. In 1976, Finance Minister Macdonald reaffirmed the government's nonmonetary diagnosis of inflation, stating: "It is frequently argued that... excessive increases 
in the money supply have been the major cause of inflation in Canada... But I do not believe they are the primary cause of the inflation we have experienced in this country" (TGM, August 19, 1976).

Indeed, as they watched inflation fall during the controls period, policymakers appear to have had too much confidence that the decline represented the genuine removal of inflationary pressure. Just eight months into the controls, Bank of Canada Governor Bouey stated that it was "within the realm of possibility that receding inflation will permit a gradual moderation of money supply growth without the need for significantly higher interest rates than we have at present," and that "in an atmosphere of growing confidence that inflation was being brought under control... interest rates could over time be expected to begin declining" (TGM, June 24, 1976). This message would have been unexceptional during a period of no price controls. But in a period where an observed decline in inflation was virtually inevitable because of the controls, the message would have helped encourage expectations of interest-rate cuts to accompany the decline. By early 1977, the Bank of Canada had indeed cut shortterm nominal interest rates down to levels below those prevailing at the start of price controls.

In addition, the post-1973 slowdown in potential growth had become a new source of output-gap mismeasurement. Contemporary observers of the Canadian economy initially mistook much of this slowdown as reflecting weakness in demand - a misconception paralleling the U.S. situation, studied by Orphanides (2003). As figure 7 shows, the OECD's 1977 estimates of Canada's output gap were far more negative than now seem appropriate. ${ }^{10}$ Subscribers to a monetary view of inflation, such as Laidler (1978), questioned these gap estimates on the grounds that they were inconsistent with Canada's severe inflation. Cost-push adherents, on the other hand, felt that severely negative output gaps and high inflation were compatible.

While cost-push views do appear to have discouraged the authorities from implementing a sufficiently tight monetary policy over 1975-78, such views did lead to a genuine disinflation beginning in

\footnotetext{
${ }^{10}$ As late as March 1977, a Canadian financial columnist described 5 percent as "Canada's long-term average rate of real growth," and characterized the Bank of Canada's monetary targets as guided by that rate (FTC, March 14, 1977).
} 
1978. Just as in the United States in the same year (see Nelson 2004, sec. 5), a fear based on a cost-push scenario - a wage-price spiral triggered by exchange-rate depreciation - triggered a monetary tightening. The deputy governor of the Bank of Canada explained that the bank in 1978 was "raising domestic interest rates repeatedly" out of concern that "the direct impact on Canada's price level of further substantial exchange [rate] depreciation could... set off a renewed outbreak of serious wage inflation" (Freeman 1981, 200). Trudeau himself claimed in October 1978 that "inflation is coming in from outside, very simply because of the high cost of things we import, and very simply because of the lowered value of the [Canadian] dollar" (CPD, October 12, 1978, p. 33). Finance Minister Chrétien blamed the revival of inflation on "the rise in food prices and the fall in the dollar" and endorsed the fear that these would trigger "a fresh outbreak of large, leap-frogging wage and price increases" ( $C P D$, November 16, 1978, p. 1200).

According to an orthodox (monetary) view of inflation, this import-price-push view was invalid - depreciation could not trigger a new inflation spiral unless the depreciation was itself a symptom of excessive demand created by the government. Despite its misguided character, however, the import-price-push view was important, both in Canada and the United States, in shifting monetary policymakers to a tighter position in late 1978 . The tighter policy eventually produced dividends in lower inflation: four-quarter CPI inflation peaked in Canada in mid-1981 and fell below 5 percent by the end of 1983 .

\section{Australia}

Australia never had compulsory price controls of the type imposed in Canada, but in other respects was more immersed in a nonmonetary tradition of inflation control that lingered until the 1990s.

\subsection{1-72: Blaming Wage-Push}

In the fourth quarter of 1970, annualized CPI inflation was 7.7 percent and the four-quarter rate reached 4.9 percent; both were the highest rates in Australia since the mid-1950s. The inflation breakout occurred during the term of office of the government headed 
by Liberal Party leader John Gorton. ${ }^{11}$ In response, Prime Minister Gorton gave a televised address to the nation on January 29, 1971, in which he blamed inflation on wage-push. Gorton ruled out "taking monetary and fiscal measures at this time," stating that his government did not "believe the present situation requires a lift in interest rates, already high" (SMH, January 30, 1971). Three weeks later, Gorton reaffirmed that "the real problem... is cost-push inflation," and maintained that the "biggest single influence now which can prevent inflation is a conscious and firm effort on the part of wage-fixing tribunals" ( $A P D$, February 18, 1971, p. 314). The cabinet minister with responsibility for labor market issues, B. M. Snedden, maintained that "excess demand does not presently exist" and agreed that the "answer to the present problems is that there should be more restraints on wages" ( $A P D$, February 18, 1971, pp. 307, 308). ${ }^{12}$

For some months in late 1971, the government (now led by William McMahon) did pursue measures to rein in demand. This did not represent an abandonment of its wage-push diagnosis, but instead reflected a fear that wage increases could lead to demand pressure. Inflation did fall in 1972, but in the meantime, the apparent failure of inflation to respond to demand restriction validated the government's earlier diagnosis of autonomous wage-push. Prime Minister McMahon denied responsibility: "It is obvious that the rise in the consumer price index is due mainly to cost increases brought about by very large wage increases. It is plainly absurd for the Leader of the Opposition to attribute the rise to the Government" ( $D M$, October 22, 1971).

The severity of the government's demand restriction was overestimated by observers, with the Institute of Applied Economic and Social Research claiming: "At no other time during the past eight years has there been such a high percentage of idle capacity" (TA,

\footnotetext{
${ }^{11}$ In Australia, the principal conservative party is known as the Liberal Party, with the Australian Labor Party its main electoral opponent. In the period studied here, the Liberal Party headed a government until December 1972, and was followed by Labor for two terms (1972-75). The Liberals then headed a government for three terms from 1975 to 1983, after which Labor served four terms over 1983-96.

${ }^{12}$ Snedden had also put on record the government's support for the viewan important part of the cost-push position - that demand did not exert upward pressure on prices until full employment was reached (Department of Labour and National Service 1970, 17).
} 
December 29, 1971). Arguments that demand stimulus would reduce inflation became prevalent, with business columnist Warren Beeby judging that "[i]n the present economic climate, a reduction in interest rates is more likely to act against inflation than feed it. It would relax some of the cost pressures, stimulate demand, and get industry moving again..." (SA, September 19, 1971). A commercial bank advised: "Greater spending would stimulate an expansion of production [and] reduce unit costs..." (TA, November 20, 1971). Over 1972 the government eased monetary policy and, late in its term, was still being described as "leaning heavily on the argument that wage increases cause inflation" (TA, August 3, 1972).

\subsection{2-73: Monetary Tightening and Push for Controls}

Despite its cost-push explanation of 1972's inflation, the Treasury was aware that the undervalued dollar and accompanying rapid money growth meant the prospect of excessive demand in 1973. In light of these concerns, the Labor government of Gough Whitlam, elected in December 1972, revalued the Australian dollar and introduced foreign exchange controls, both of which worked in the direction of reducing money growth. To this extent, the government was now taking conventional monetary measures against inflation. A submission to cabinet by the Assistant Treasurer in October 1973 reveals, however, that the authorities' views remained unorthodox in important respects $(A C R$, October 5,1973$)$. This document classified inflation, which was now moving into double digits, as falling into three categories: imported inflation, which it characterized as working not only through the effect of balance-of-payments surpluses on the money supply, but also "through rising import prices; cost inflation; and demand inflation, occurring when "demand... run[s] beyond the capacity of supply." This classification scheme amounted to a cost-push approach to inflation, supplemented by an acknowledgment that the output gap matters for inflation when the gap is positive. By contrast, a monetary view of inflation would not categorize cost and imported inflation as distinct from demand inflation, but as simply routes through which excessive demand is transmitted to the inflation rate.

The government's classification of inflation into three distinct types is also reflected in the three main actions it took as 
anti-inflationary policy in the second half of 1973: tariff cuts; a monetary tightening; and proposed wage and price controls.

The government announced a 25 percent tariff cut in July 1973 with the statement: "The justification for the general reduction of tariffs is the excessive rate of inflation which now prevails... The tariff changes will have a direct impact on import prices of about the same magnitude as an Australian revaluation of slightly less than 6\%" (TA, July 19, 1973). This equivalence rests on the observation that both actions withdraw import-price-push pressure on prices. But from a monetary view of inflation, revaluation and tariff cuts are not equivalent. Revaluation drains aggregate demand and reduces pressure on prices by creating a balance-of-payments deterioration and thereby producing monetary contraction. A tariff cut, by contrast, need have no such effects. Prime Minister Whitlam would adhere to the import-price-push view well after he left office, maintaining in a 1977 television interview that "the biggest component of inflation at the moment in Australia is Australia's excessive protectionism" ( $M C$, September 19, 1977).

Action was taken to reduce money growth with a 5 percent revaluation in September 1973, accompanied by an announcement by the Prime Minister of "a sharp rise [about 2 percent]... in interest yields... an essential precondition if inflation is to be countered at all" $(S M H$, September 10, 1973). The reference to monetary restraint as a "precondition" for inflation control again left open the possibility that some inflation was of a nonmonetary variety.

The third measure against inflation by the government during 1973 was an effort to introduce compulsory wage and price controls. Since it lacked the constitutional powers to impose wage and price controls, the government held a referendum in December 1973 to obtain those powers. The referendum proposals were defeated on December 8, 1973.

\subsection{4-75: Abandoning Monetary Solutions}

As of late 1973, the Australian authorities were pursuing a largely orthodox economic package - employing monetary restriction rather than price controls - against inflation. That policy would eventually produce dividends in the form of falling inflation in mid-1975. By then, however, the government had become disillusioned with 
monetary restraint as a cure for inflation and had embraced a nonmonetary approach.

This shift was largely a response to 1974's stagflation. While the strict monetary policy of $1973-74$ did cut deeply into aggregate demand, it happened to coincide with a shift to a lower path of potential output, due to permanent shifts in the labor market and the post-1973 productivity slowdown. The government incorrectly perceived a severely negative output gap. It was not until June 1975 that Treasurer Cairns publicly acknowledged that "the minimum level of unemployment will be considerably higher than in the past decade" ( $T A$, June 5, 1975), while the slowdown in potential growth took years to recognize. With aggregate supply actually falling nearly as much as aggregate demand, the fall in inflation was not only delayed but modest. The apparent emergence of prolonged inflation alongside a deep output gap led Prime Minister Whitlam himself to adopt a strict cost-push diagnosis of inflation. "I have to be quite frank with you," he said in a televised address to the nation, invoking import-price-push, "inflation will not be wholly beaten until there is a worldwide solution" (DT, August 27, 1974). In October 1974 he placed emphasis on wage-push as the source of inflation: "There should be no doubt that this severe inflation will continue if there are excessive wage claims" (TA, October 22, 1974).

A mini-budget delivered by Whitlam in November 1974 outlined the government's change in strategy. He now rejected aggregate demand limitation as an essential ingredient in inflation control, instead claiming "[w]hat is needed is a stimulus to the economy which increases demand, whilst at the same time abating cost pressures" ( $A P D$, November 12, 1974, p. 3360). To this end, he had approved "a very substantial relaxation of monetary policy," while his statement announced cuts in personal income taxes. He argued that the tax cut would both stimulate demand and serve as a direct "attack on inflation, by reducing wage pressures" ( $A P D$, November 12, 1974, p. 3361), since disposable incomes could now rise without wage increases. The government was therefore pursuing a voluntary incomes policy based on a wage/tax-push view of inflation.

Not only did the government no longer view demand restraint as an essential part of an anti-inflation program, it now contended that monetary restriction actually promoted inflation. Treasurer Cairns said that tight monetary policy in 1974 had made unemployment 
and inflation worse because it had been introduced when excess demand was ceasing to be a problem ( $T A$, June 5, 1975), an argument he based on interest-cost-push and unit-cost-push views of inflation ( $M E H$, September 23, 1975).

\subsection{6-79: Sending Mixed Signals}

The Liberal government that took office in late 1975 ostensibly accepted an important role for monetary policy in the control of inflation, with steps to reduce money growth announced in January 1976 and targets for growth in M3 commenced in March 1976. In practice, however, inflation in the double-digit range was a problem for the whole life of the government. The government made little progress in reducing inflation after its first two years in office, and with the lag between monetary policy actions and inflation, the initial reduction is best attributed to the reining in of money growth that occurred in 1973-74 under Whitlam. It was not until 1980 that the government's monetary policy became more genuinely anti-inflationary, and - again due to lags - this did not deliver a substantial fall in inflation until after the government lost office in 1983.

In part, the government's failure to achieve a major monetary tightening earlier than 1980 is attributable to its flawed execution of monetary targeting. In contrast to Whitlam's tightening in 1973, open market sales and increases in short-term interest rates were typically eschewed in favor of heavy use of reserve-requirement changes. Indeed, the January 1976 package of measures to reduce money growth was accompanied by an announced reduction in official shortterm rates (AFR, January 23, 1976). The reliance on quantitative controls is reflected in the fact that the compulsory cash-reserve requirement was changed eighteen times over 1976-79. Such actions should not have been regarded as effective, because with an unchanged policy rate, a higher reserve requirement leads to the extra monetary base being created by the central bank, with no downward pressure on deposit growth or aggregate demand. An additional error was that the authorities falsely believed that budget deficit reductions made an automatic contribution to restricting money growth. Indeed, The Economist characterized the government's strategy in 1978 as using deficit control to reduce money growth "without a rise 
in interest rates" (TE, August 19, 1978) - this at a time when real interest rates were close to zero.

The government sent further mixed signals on inflation control because its adoption of monetary targeting was by no means accompanied by abandonment of the cost-push analysis of inflation. Both Prime Minister Fraser and Treasurer Lynch believed that wagetribunal decisions could add directly to inflation, with Fraser saying they contributed to "this vicious spiral of higher prices, higher money wages, higher costs, and yet more price increases" (DT, February 14, 1976) and Lynch arguing that "excessive wage and salary claims remain a direct impetus to more inflation" (DM, February 20, 1976). In fact, the government unsuccessfully attempted in April-May 1977 to arrange a wage-price freeze, a measure Fraser claimed would "break the back of inflation" (TE, April 16, 1977).

This shows that the government's misguided means of pursuing monetary targets were not just a technical error - they were founded in the cost-push approach. Low real interest rates should have signaled to the government that it had not actually tightened monetary policy substantially. But the above statements show that the authorities believed that wage-price spirals could occur without monetary accommodation, and that a price freeze could break inflationary expectations. They could therefore attribute low real interest rates to autonomous movements in expected inflation, to be remedied by direct intervention in wage and price setting rather than by higher nominal interest rates.

As figure 8 indicates, another impediment to tighter policy was a still erroneous picture about the state of demand. In October 1977, The Economist expressed the widespread view that "the Australian economy is operating at well below capacity" (TE, October 29, 1977), an assessment that reflected the continued failure to recognize the post-1973 slowdown in potential GDP.

\subsection{0-82: Moving to a Stricter Rule}

Around 1980, the Australian authorities do appear to have shifted to a more genuinely anti-inflationary stance. The real ex-post Treasury bill rate was 2.4 percent in the first ten quarters of the $1980 \mathrm{~s}$, higher than in any ten-quarter period since 1962-64; furthermore, discrepancies between actual interest rates and Taylor rule prescriptions 
became less striking (figure 5). It therefore appears appropriate to characterize policy from 1980 as the adoption of a more restrictive interest-rate rule. This change may have been a response to criticism in public debate of quantitative controls and calls for a more market-oriented monetary policy (see Guttmann 2004). The tighter policy also probably reflected the recognition that Australia's slower growth after 1973 was supply-side in character. The more inflationoriented monetary policy helped deliver better inflation performance after 1982. This improvement was marred by two major revivals, in 1985-86 and 1988-90. Both occasions of higher inflation reflect lapses by the authorities back into nonmonetary strategies against inflation.

\subsection{2-84: Lapse into Monetary Policy Neglect}

The early 1980s monetary tightening in Australia was initially felt only in recession, while wage and price inflation increased, reflecting delayed responses to past monetary ease. By late 1982, the Fraser government had reverted to a more stimulative policy on aggregate demand, and in October 1982, with four-quarter CPI inflation having reached 12.3 percent, Prime Minister Fraser announced his support for a six-month wage freeze ( $D M$, October 26,1982$)$. The claimed rationale for such a freeze was that it would simultaneously reduce inflation and unemployment, and when the government formally advanced the plan, it estimated that the freeze would reduce inflation by six percentage points $(A F R$, December 17,1982$)$. The wage freeze was agreed to by the state governments and wage tribunals, and became effective in December 1982. Thus, at the end of 1982, Australia was pursuing a stricter incomes policy than it ever had in the 1970s.

The Hawke government that came into office in March 1983 eventually brought inflation below 5 percent, though not until 1991. In the intervening years, it deployed a number of nonmonetary strategies against inflation and experienced the usual disappointments with these approaches. The centerpiece of these nonmonetary tools was the "Accord," an agreement on wage growth between the government and labor unions. Early in the government's term, Treasurer Keating indicated that this incomes policy would not be used as a substitute for aggregate demand policies against inflation; this, however, proved a short-lived position (Kelly 1992, 66), and Keating was reported in September 1983 as believing that Australia's 
wage-fixation system made inflation difficult to control via demand weapons $(D M$, September 8, 1983). The government also continued an expansionary monetary policy and reaffirmed its view of incomes policy as a weapon that could help reduce the reliance on demand management. In August 1983, Prime Minister Hawke made it clear that he saw incomes policy as an alternative to the "traditional instruments of tighter monetary and fiscal policy to restrain inflation" (TA, September 1, 1983).

In January 1985, the government faced a decision on whether to tighten monetary policy after growth in the M3 aggregate persistently exceeded the target rate. It was widely accepted that M3 behavior reflected distortions from financial innovation, but other monetary aggregates less subject to distortion also suggested easy money conditions, while real interest rates-though well above 1970s values - had been slightly below U.S. levels during most of 1984, even as Australia had more serious inflation. The government's decision to drop the monetary target, and not tighten monetary policy at all, was applauded by the Sydney Morning Herald in an editorial: "[M]onetary policy is anything but loose. Any further tightening of monetary policy... would be more likely to fuel inflation than control it... [because with] the Accord, the Government has promised to deliver employment and economic growth" $(S M H$, January 30, 1985). Thus, three years after monetary policy had produced disinflation in major economies, the argument that monetary tightening worsened inflation was still being prominently advanced in Australian policy debate.

\subsection{5-91: Discarding the Nonmonetary Framework}

The position that monetary policy was already tight, and that further tightening would relaunch inflation, was not borne out by developments in the rest of 1985 . Faced with a resurgence of inflation, the government tightened monetary policy beginning in February 1985. The fact that monetary policy was tightened when inflation rose, despite the continuing prevalence of cost-push views among policymakers, reflects the import-price push diagnosis of the inflation outbreak. Even from a cost-push perspective, monetary tightening is the appropriate response to rising inflation if the rise is believed to have come from exchange-rate depreciation. 
In contrast to the fears expressed earlier in 1985, monetary tightening did not produce a wage-price spiral. Price inflation receded in 1987-88, reflecting a delayed reaction to the 1985-86 tightening, while wage inflation was lower still, in part reflecting continuing attempts to use control of wages as an anti-inflationary weapon. To this end, the government negotiated over 1985-86 a trade-off between nominal wage increases and tax cuts.

Contrary to their aim, the 1980s incomes policies in Australia appear to have contributed little or nothing to the control of inflation. Price inflation in the 1980s behaved dissimilarly to wage inflation; as one of Keating's subsequent advisers observed, incomes policy appeared "extremely successful in restraining the growth of wages but not of inflation" (Edwards 1996, 282). Policymakers attributed this failure first to import-price-push and then to profit-push. In fact, however, it appears that it was the absence of monetary restraint that really made the difference, as price inflation in the 1980 s responded quite predictably to prior monetary developments. ${ }^{13}$

Monetary policy setting in the 1980s was made more complicated by the global rise in real interest rates. But by the mid-1980s the experience of disinflating countries should have made it clear to the Australian authorities that the average real rate consistent with price stability was higher than in, say, the 1960s. Overconfidence in incomes policy, not uncertainty about real rates, explains why Treasurer Keating predicted in May 1988 that "inflation [is] now heading towards 5 percent or lower" (APD, May 25, 1988, p. 3013), despite nominal interest rates having been cut by 6 percentage points (and real rates by around 3 points) over the course of 1987 .

Satisfied that inflation control had been successfully delegated to other devices, the authorities thus permitted monetary ease over 1987-88, an easing reflected in a surge in inflation over 1988-90. In addition, 1988 brought a new series of nonmonetary initiatives against inflation. Many of them were introduced in the August

\footnotetext{
${ }^{13}$ For the period of strictest wage control, 1983-89, the correlation of CPI inflation and growth in average nominal wages is -0.22 ; the maximum positive correlation of inflation with prior wage growth is 0.42 (inflation and wage growth one year earlier). By contrast, the maximum correlation of inflation and money (currency) growth is 0.61 (inflation and money growth two years earlier). Another measure of monetary ease - the excess of the Taylor rule prescriptions in figure 5 over actual short rates-leads inflation over $1983-89$ by one year, with a correlation of 0.85 .
} 
1988 budget, as a newspaper report recorded: "The Budget's antiinflationary strategy hinges on lower indirect taxes, mainly for beer drinkers, and a delay in personal tax cuts... [T] he size of the [income tax] cuts will depend on the second wage/tax trade-off..." (TA, August 24, 1988). Reflecting on these measures, Treasurer Keating remarked, "Having succeeded in bringing down the inflation rate of 11 per cent under the Liberal Party to 5 per cent in 1985, and having watched inflation rise to 10 per cent as a result of a big depreciation of the exchange rate, we are now succeeding in bringing it back to the 5 per cent area whence it came in $1985 \ldots$ Inflation is declining" (APD, November 30,1988 , p. 3547). But inflation actually rose from its 1988 Q1 trough of 6.9 percent, ending the 1980s at a four-quarter rate of 7.8 percent.

A major monetary policy tightening also occurred in 1988 . The tightening itself was motivated by balance-of-payments rather than inflation considerations. The fall in inflation that it produced, however, transformed the views of policymakers and observers about the role of monetary policy in inflation control. As late as 1990, the governor of the Reserve Bank rejected central-bank inflation targeting as infeasible in Australia, and cited the need for other tools such as wages policy ( $A F R$, October 18, 1990). When inflation fell below 5 percent in early 1991 - clearly a response to the period of monetary restraint - Treasurer Keating spoke publicly about low inflation as the criterion by which macroeconomic policy should be judged (Edwards 1996, 405). Gruen and Stevens $(2000,52)$ record that in the 1990s, "the main insight of two centuries of monetary economics. . that monetary policy ultimately determined inflation" convinced the authorities that nonmonetary approaches to inflation control should be abandoned in favor of central-bank inflation targeting.

\section{New Zealand}

In the 1970 s and 1980 s, decisions on monetary policy were the responsibility of the New Zealand Treasury, headed by the Minister of Finance. In May 1970, Finance Minister Robert Muldoon rejected private estimates that inflation in New Zealand, which stood above 4 percent, might reach 9 percent later in the year. Muldoon noted that New Zealand's experience was of lower inflation than in Japan, the United States, Canada, and the United Kingdom (EP, May 6, 
1970). Building on this comparison, Muldoon said that "countries which fail to hold inflation will suffer in comparison with those which are successful. This is the test..." (EP, July 21, 1970). Over the following fifteen years, during which Muldoon totaled eleven more years as Finance Minister, New Zealand performed poorly by this test. In 1985, New Zealand's CPI averaged 5.7 times its 1970 value, compared to 2.7 in Japan, 2.8 in the United States, 3.1 in Canada, 4.1 in Australia, and 5.0 in the United Kingdom. The deterioration reflected repeated application by the authorities of the policy combination associated with monetary policy neglect - direct wage-price controls accompanied by monetary expansion.

\subsection{0-72: Rival Spiral Theories}

The government had predicted in mid-1970 that inflation for the full year would be a little over 4 percent (EP, May 29, 1970). By the end of 1970, four-quarter CPI inflation was instead moving into double digits. Muldoon cited "a wage/price spiral caused... by the stronger and more militant unions" (NZPD, June 25, 1970, p. 1298), while the Reserve Bank of New Zealand similarly judged that "[t]he "costpush' type of inflation now seems to be dominant" (RBNZ, April $1970)$. The government imposed a three-month wage-price freeze in November 1970 and negotiated with unions for a voluntary wages policy to follow the freeze. After the negotiations failed, the government introduced a compulsory policy accompanied by continued monitoring of prices.

The opposition, headed by Labour Party leader Norman Kirk, had its own cost-push diagnosis of inflation. Kirk rejected the wagepush explanation on the grounds that "wages and salaries were increased because costs and prices had increased" (NZPD, June 15, 1971, p. 853). Instead he blamed a "cost-tax-price spiral" initiated by government tax increases (NZPD, June 15, 1971, p. 854). The government and opposition thus had rival "spiral" theories of inflation-a wage-price spiral versus a cost-tax-price spiral - neither of them consistent with a monetary explanation.

Kirk also endorsed the unit-cost-push argument that demand restriction worsened inflation: "Stagnation is a cause of inflation... [by] compelling factories to run at less than full capacity so that the unit cost remains high but the volume of output falls... If we want 
to cure inflation, we must first increase production" (NZPD, June 14, 1972, pp. 116-17). Even the premise of Kirk's argumentthat demand was weak in 1972-has no support in revised data (figure 9).

By 1972, however, the government shared Kirk's view that the output gap had gone negative. This perceived deterioration had occurred alongside continued double-digit inflation through most of 1971, so the government's cost-push diagnosis was reinforced. The Reserve Bank of New Zealand claimed that in "a period of 'stagflation'... orthodox monetary policy is of subsidiary importance" (RBNZ, April 1972). Similarly, Muldoon claimed that recent overseas attempts to fight inflation with monetary restriction had raised unemployment without reducing inflation (NZPD, June 10, 1971, p. 785).

In light of these judgments, the government in March 1972 increased its range of direct controls-imposing stricter controls over firms' price decisions, freezes on prices of government output, and limits on dividend income (NZPD, June 22, 1972, pp. 391-92). The government also undertook monetary and fiscal expansion. In line with the cost-push view, it believed that pressure on inflation from demand only began once the economy reached potential, which Muldoon said was far off, given the "unused capacity in the economy" (NZPD, June 22, 1972, p. 409).

The timing of Muldoon's policy loosening was far from appropriate as, like Australia, New Zealand had entered a period of tremendous increases in the monetary base due to large inflows of foreign capital and export earnings. Muldoon's monetary easing was a response to the more restrained pre-1972 demand environment, which the external developments had already replaced with boom conditions. The earlier period of weaker demand, as well as the controls imposed by the government, nevertheless secured a fall of inflation to just above 5 percent by the end of 1972 .

\subsection{2-75: Labour Government}

The National Party administration was defeated at the election of November 1972 and was succeeded by a Labour government led by Norman Kirk. The government was immediately faced with a revival of inflation, which in the first quarter of 1973 returned to double-digit 
annualized rates. The authorities took a strict cost-push interpretation of the increase. Presenting the government's 1973 budget, Finance Minister Rowling acknowledged that "inflation has become the number one problem" (NZPD, June 14, 1973, p. 1353), but insisted that "short-term economic management must keep the economy running close to full capacity" (p. 1349). To this end, the government actually cut the Treasury bill rate by 50 basis points to 2 percent in May 1973 (RBNZ, April 1974). The measures Rowling outlined to "contain the inflationary pressures which are apparent" ( $N Z P D$, June 14, 1973, p. 1349) consisted of interventions in the markets for particular goods.

Prime Minister Kirk returned from an overseas visit in August 1973 claiming inflation was a mystery: "So far, nobody has been able to say what is causing inflation, let alone suggest a remedy for it" (EP, August 16, 1973). His own account of New Zealand's inflation was that "living costs have risen because of the price of meat" (NZPD, September 1, 1973, p. 3422). In addition, he blamed importprice-push: "we are also feeling the effect of inflation in the Northern Hemisphere through a sharp and very severe rise in the prices of our imports." The import-price-push analysis would produce the main monetary tightening of the year - the exchange-rate revaluation in September 1973.

New Zealand's announcement of a 10 percent revaluation was synchronized with the revaluation taking place in Australia. However, in contrast to the statement by Prime Minister Whitlam in Australia, which had mentioned the need to curb money growth, Kirk's rationale for the revaluation concentrated on the importprice-reducing aspects of the action. "The increasing cost of imports and the higher prices of meat and other goods which we export have been major causes of the rising cost of living in New Zealand... A major threat to cost and price stability that we face now is the surge of inflation reaching New Zealand from abroad," he told a press conference. He argued that the revaluation would be anti-inflationary via "a reduction... in the cost of imported goods and of those export commodities whose prices tend to be determined in overseas markets... [with] further benefits as these price effects work their way through the national cost structure" ( $C P$, September 10, 1973). Other than a brief reference to the strength of New Zealand's overseas reserves, the implications of the revaluation for 
monetary and aggregate demand conditions went unmentioned by Kirk, even though, from the perspective of a monetary view of inflation, these were the most important aspects of the policy action.

Consistent with the government's rejection of excess demand as a source of inflation, Kirk's revaluation announcement was not accompanied by interest-rate increases; rather, the accompanying measures were a range of new controls on the prices and export of agricultural goods $(N Z H$, September 10, 1973). The four-quarter rate of CPI inflation ended 1973 at 10 percent, nearly double its value a year earlier. Finance Minister Rowling attributed the increase in the inflation rate during 1973 to "three major factors: meat prices, governed by overseas realizations; fruit and vegetable prices, governed by the weather in this country; and import prices, governed by other people's costs. None of these things comes very directly within the control of the Government" (NZPD, June 5, 1974, p. 1642).

Later in 1974, the authorities turned to blaming domestic wagepush for inflation. The government (now led by Rowling after Kirk's death) introduced new controls on wage growth and in 1975 negotiated wage agreements with labor unions ( $R B N Z$, April 1975). Finance Minister Tizard claimed that "an effective incomes policy is crucial in the current economic situation... a relaxation of controls on wage bargaining is directly dependent on a moderation of our present inflation" (NZPD, May 22, 1975, p. 1295). Prime Minister Rowling rejected demand contraction on the grounds that it had been tried overseas and had caused unemployment with little effect on inflation. Instead, he described his task as to "ensure that there is the least possible disruption to sustained economic growth and employment" ( $E P$, December 3, 1974).

\subsection{6-79: Misleading Austerity}

Following the November 1975 election, the National Party returned to office, now led by Robert Muldoon who, in addition to becoming Prime Minister, resumed his former position of Finance Minister. Throughout his term in office, Muldoon maintained cost-push views of inflation. He nevertheless consciously pursued a policy of zero real GDP growth in 1976; the rationale for this strategy was to improve the current account balance rather than inflation ( $C P$, January 13 , 1982). The government announced a tightening in March 1976, with 
a 100 basis point increase in Treasury bill rates to 4 percent $(R B N Z$, April 1976). With inflation at over 15 percent, this still implied highly negative real rates. Real rates were nevertheless less negative than they had been in 1975, and this, along with the slowdown of money growth that had occurred after 1973, produced somewhat more restrained monetary conditions in the mid-1970s than had prevailed earlier in the decade.

A slowdown in the economy did occur over 1976-77, and this slowdown, in turn, accounts for the decline in inflation to around 10 percent in late 1978. The reason why inflation did not fall further is that in terms of excess demand, the measures to restrict demand were nowhere as austere as thought at the time, because potential output growth had undergone a particularly severe slowdown (table 1). As in other countries, the authorities were slow to recognize the reduced growth of supply; and, again as in other countries, in the meantime they observed protracted periods of high inflation and negative gaps, seemingly confirming cost-push views of inflation. It was not until 1978 that the Reserve Bank of New Zealand made it clear that "New Zealand's slow growth reflects fundamental structural factors" (RBNZ, April 1978).

Growing recognition of the productivity slowdown had no effect on the Muldoon government's adherence to nonmonetary views on inflation. Muldoon imposed a four-month freeze on prices in late 1976; when inflation continued after the freeze's removal, he claimed, "Two main factors are maintaining the present inflationary momentum. These are import prices and wages" (NZPD, July 21,1977 , p. 1525). Giving little role to monetary policy in his antiinflation strategy, Muldoon allowed policy to ease during 1978, and by the end of the 1970s, inflation was close to its 1970s peak of 17 percent.

\subsection{0-84: Reaffirming Nonmonetary Approaches}

In January 1980, while several major economies were assigning a central role to monetary policy in fighting inflation, the Muldoon government continued to adhere to the view that inflation was largely beyond the reach of macroeconomic policy. "New Zealand is, of course, still vulnerable to overseas influences, particularly oil prices, and to domestic factors, such as wage increases," Muldoon said. "What 
happens to prices over the coming year will be determined largely by these two factors" ( $C P$, January 14, 1980). Shortly afterward, fourquarter CPI inflation reached a peacetime peak of over 18 percent, a rate which Muldoon claimed was "almost entirely" due to the second oil shock (AST, October 2, 1981).

The wage-push diagnosis of inflation led the Muldoon government to attempt to negotiate a wage/tax trade-off with trade unions over 1981-82. ${ }^{14}$ When these negotiations broke down, Muldoon imposed a one-year wage-price freeze. Muldoon's justification for the freeze cited developments in major OECD countries. "Rates of inflation in most of these countries are declining... These countries are major suppliers of products to New Zealand... The price of oil is expected to decline in real terms throughout the remainder of this year... All of these things give us a unique opportunity to reduce New Zealand's rate of inflation..." (NZH, June 23, 1982).

The political reaction to the controls announcement was a watershed, reflecting the increased role since 1980 for conventional economic analysis in New Zealand debate. Opposition leader Rowling gave an orthodox critique of Muldoon's freeze:

"The wages and prices freeze will not work. . After all, in the year A.D. 301, a little before the Minister of Finance's time, but not before the policies adopted by the present Government - that dates the policies - the Emperor Diocletian introduced a price freeze with the death penalty for non-compliance, and it still did not work. There is no way in which it will work in 1982, any more than it [c]ould in A.D. 301, because such a proposition resolves absolutely nothing." (NZPD, July 20, 1982, p. 1199).

Similarly, Rowling's successor as Labour Party leader, David Lange, said that New Zealand's trading partners had reduced inflation by tightening monetary policy, while Muldoon's government had undertaken no such attack on the causes of inflation $(C P$, July $11,1983)$.

\footnotetext{
${ }^{14}$ The Reserve Bank governor also voiced support for an incomes policy, stating: "I don't believe inflation, which is well-entrenched and is being encouraged by the close linkage between costs and prices, can be overcome solely by tight monetary and fiscal policies" (NZH, February 13, 1982).
} 
For his part, Muldoon in his 1983 budget claimed that "monetary restraint" had accompanied the wage-price freeze (NZPD, July 28, 1983 , p. 891). In fact, however, the government followed an expansionary policy. Muldoon made it clear that he had no intention of reining in demand during the freeze: "I would think that we should be able to keep the general level of economic activity high enough that there should be no big increase in unemployment" ( $C P$, December 28 , 1982). In July 1983, Muldoon reduced the interest rate on threemonth Treasury bills from 12 percent to 7.8 percent (AST, July 30, 1983). His rationale made it clear that his concept of "monetary restraint" involved making real rates positive by suppressing inflation, not by increasing nominal rates: with inflation down to 4 percent, he said, an 8 percent nominal return was "pretty reasonable" ( $E P$, October 13, 1983).

The evolution of macroeconomic policies during the freeze thus confirmed a fear expressed by Don Brash, later head of the central bank, but in 1982 a newspaper columnist. At the time of the freeze's imposition, Brash worried that the worst side effect of the freeze would be that it would "fool people into believing that something is actually being achieved in the reduction of inflation," at the same time that the government did nothing to reduce monetary growth (AST, June 23, 1982). The appearance of success proceeded as the four-quarter CPI inflation rate fell into single digits in mid1983, troughing at 3.5 percent at the end of the year, by which time the freeze had been extended to February 1984. A member of Muldoon's cabinet, Foreign Affairs Minister Cooper, declared victory: the government, he said, was the first in the history of Western civilization to have cured inflation successfully via a wage-price freeze (CP, September 17, 1983).

The illusory nature of this improvement was revealed in July 1984, when CPI data for the first post-freeze quarter revealed that prices had jumped by 2.2 percent (CP, July 10, 1984). Shortly afterwards, the Muldoon government suffered electoral defeat.

\subsection{4-90: From Price Controls to Inflation Targets}

Immediately upon taking office, the Labour government tightened monetary policy. Short-term interest rates increased sharply and in 1985 took positive real values for the first time (excluding the freeze 
period) since 1969. Finance Minister Douglas justified the interestrate increases on the grounds that they would "assist in keeping both inflationary pressure and inflationary expectations down" $(C P$, August 3, 1984), a contrary judgment to that of defeated Prime Minister Muldoon, who deplored the changes on interest-cost-push grounds ( $C P$, July 19, 1984). Given the lagged response of inflation to monetary policy actions, the monetary policy tightening begun in 1984 did not prevent higher inflation over 1985-87-a rise reflecting the earlier period of monetary ease, the removal of remaining price controls, and the impact effect of higher indirect taxation. Inflation did, however, fall into single digits at the end of 1987, and the fourquarter rate fell below 5 percent at the end of 1988. Also in 1988, the government appointed Don Brash as governor of the Reserve Bank of New Zealand. Brash's view of the record of controls was negative: "Literally hundreds of governments, of all political persuasions and in all parts of the world, have tried to reduce inflation by direct controls. There is no case where controls alone succeeded" (AST, June 23, 1982). ${ }^{15}$ Over 1989-90 the authorities cemented the delegation of inflation control in New Zealand to monetary policy through their much-discussed launch of inflation targeting (see, e.g., Debelle 1996, 60-62; Bernanke et al. 1999, chap. 5).

\section{Conclusion}

The analysis in this paper indicates that the course of macroeconomic policy during the Great Inflation in Canada, Australia, and New Zealand shared four common features.

First, policymakers (at least from 1971) viewed inflation as resulting from factors beyond their control, not as a consequence of their monetary policy decisions. This rules out explanations of the Great Inflation that characterize the monetary authority as consciously choosing the inflation rate to achieve certain outcomes for real variables, or as part of an optimization exercise. Such explanations include those used in the time-consistency literature and also accounts that rely on a government belief in a permanent trade-off between unemployment and inflation. The record of policymakers'

\footnotetext{
${ }^{15}$ Similarly, Brash judged that other nonmonetary devices such as wage/tax trade-offs had "a negligible impact on inflation" ( $A S T$, June 17, 1982).
} 
views is, however, consistent with the monetary policy neglect hypothesis.

Second, nonmonetary actions against inflation were accompanied by monetary expansion, not restraint. Occasionally policymakers verbally acknowledged the need for monetary restriction to complement incomes policies, but in practice they did not follow such a combination. In particular, while recognizing that real interest rates had become abnormally low, they felt that positive real rates could be restored by direct actions against the expected-inflation component of nominal rates. On other occasions, they were quite explicit that they intended to stimulate or maintain aggregate demand while delegating inflation control to other devices.

Third, output-gap mismeasurement reinforced the tendency for monetary policy neglect. The belief that inflation behavior was proceeding in spite of negative output gaps motivated the shift to nonmonetary theories of inflation; and once nonmonetary devices against inflation had been deployed, the desire to eliminate output gaps justified monetary expansion.

Fourth, the monetary policy regime change that produced disinflation did not always coincide with a rejection of the nonmonetary view of the inflation process. In New Zealand, the adoption of firmer monetary policies did coincide with the election of a government that took a monetary view of inflation. In Australia and Canada, the monetary changes were triggered either by cost-push considerations (i.e., fear of exchange rate depreciation in Canada) or factors besides inflation (i.e., balance-of-payments considerations in Australia). The disinflations that followed, however, converted policymakers in these countries to a monetary view of inflation, an important step toward their adoption of an inflation-targeting framework.

\title{
Appendix 1. Abbreviations for Periodicals Cited in Text
}

\author{
Canada: \\ CPD-Canadian Parliamentary Debates (House of Commons) \\ FP_Financial Post \\ FTC-Financial Times of Canada \\ IFS-International Financial Statistics (Washington, DC) \\ TGM-The Globe and Mail (Toronto)
}


TSN-Toronto Sun

TST-Toronto Star

WFP_Winnipeg Free Press

Australia:

ACR-Australian Cabinet Records (National Archives, Canberra)

AFR-Australian Financial Review

$A P D$-Australian Parliamentary Debates (House of Representatives)

DM-Daily Mirror (Sydney)

DT-Daily Telegraph (Sydney)

MC-Monday Conference (television program; transcripts)

MEH-Melbourne Herald

MES-Melbourne Sun

SA-Sunday Australian

SMH-Sydney Morning Herald

TA-The Australian

TE-The Economist (London, United Kingdom)

New Zealand:

AST-Auckland Star

CP-Christchurch Press

EP-Evening Post (Wellington)

$N Z H-N e w$ Zealand Herald (Auckland)

NZPD-New Zealand Parliamentary Debates

RBNZ-Reserve Bank of New Zealand Annual Report

\section{Appendix 2. Chronological List of Newspaper Articles Cited in the Text}

\section{Canada}

Anderson, Ronald. "Jobless, Price Climate Improves." The Globe and Mail, February 21, 1969, p. B1.

Rasminsky, Louis. "Why Money Stays Tight." Financial Post, November 1, 1969, p. 6.

Cohen, Dian. "Negative Approach Wrong in Our War on Inflation." Toronto Star, February 2, 1970, p. 22. 
Cohen, Dian. "Ottawa Spending Heightens Inflation." Toronto Star, December 14, 1970, p. 13.

Ottawa Bureau. "Inflation Is Over'; Trudeau Zeroes In on Unemployment." Toronto Star, December 24, 1970, p. 1.

Cohen, Dian. "Straitjacket Thinking Won't Beat Inflation." Toronto Star, March 1, 1971, p. 9.

Editorial. "Wage-Price Freeze Could Halt Inflation." Toronto Star, August 21, 1971, p. 6.

Winnipeg Free Press, "Economic Care Needed, OECD Tells Canadians," December 28, 1971, p. 14.

Editorial. "Price and Income Controls: The Only Weapon Left against Inflation." Toronto Star, February 10, 1972, p. 6.

Cohen, Dian. "Economic Tightening Could Worsen Inflation." Toronto Star, March 27, 1972, p. 39.

McGillivray, Don. "Cure Made Inflation Worse." Financial Times of Canada, December 4, 1972, p. 3.

Westell, Anthony. "Competition Counts in Economy: P.M." Toronto Star, September 20, 1973, p. A6.

Zink, Lubor J. "There Is a Choice." Toronto Sun, March 6, 1974.

Zink, Lubor J. "Jim Gillies and Economic Truths." Toronto Sun, March 8, 1974.

Turner, John. "Turner: Stimulate Economic Expansion." The Globe and Mail, June 8, 1974, p. 7.

Editorial. "Why Did Trudeau Let It Happen?" Toronto Star, May 23, 1975, p. B4.

Cheveldayoff, Wayne. "Interest Rates Will Be Allowed to Rise, Fall as Ottawa Confirms Bank of Canada Policy." The Globe and Mail, October 15, 1975, p. B4.

Cheveldayoff, Wayne. "Bank to Reduce Money Supply Growth Target." The Globe and Mail, June 24, 1976, p. B1.

The Globe and Mail, "What Macdonald Said," August 19, 1976, p. A7.

McGillivray, Don. "Money Supply Dilemma: Growth Target Too High." Financial Times of Canada, March 14, 1977, p. 6.

Australia

Sydney Morning Herald, "Govt.'s Inflation Plans: PM Reports to Nation," January 30, 1971. 
Beeby, Warren. "Time for McMahon to Review Interest Rates, Allowances." Sunday Australian, September 19, 1971.

Daily Mirror, "That Was the Week That Was! 'Don't Blame Us for Those Price Rises," October 22, 1971.

The Australian, "Govt. Curbs on Demand Seen as Inappropriate," November 20, 1971.

The Australian, "Call for a Unified Policy on Inflation," December 29, 1971.

Editorial. "Taxation Burden Is Intolerable." The Australian, August 3, 1972.

The Australian, "Tariff Cuts to Hold Prices: Increased Imports Will Give More Competition," July 19, 1973, p. 9.

Sydney Morning Herald, "Govt. Acts to Stem Inflation," September 10, 1973.

Hayden, W. G. "Inflation." Submission to Federal Cabinet, October 5, 1973, Australian Cabinet Records 1973 (declassified 2004).

Forsyth, Chris. "Gough Pledges Steady Budget." Daily Telegraph, August 27, 1974, pp. 1-2.

Kelly, Paul. "PM Blames Pay Claims for Jump in Inflation." The Australian, October 22, 1974, pp. 1 and 3.

Savva, Niki. "Industry May Get Subsidy to Hire Jobless." The Australian, June 5, 1975, pp. 1-2.

Cairns, J. F. "Only a New Society Can Cure Inflation." Melbourne Herald, September 23, 1975.

McGuinness, P. P. "Fraser's New Monetary Package: Interest Rate Cut-Money Supply Also." Australian Financial Review, January 23,1976 , pp. 1 and 4.

Daily Telegraph, "Inflation Now a Tougher Task, Says Fraser," February 14, 1976, p. 2.

McGarry, John. "WWage Inflation Curbs Still Needed.'” Daily Mirror, February 20, 1976, p. 11.

Oakes, Laurie. "What I'd Do Now, by Gough Whitlam, Talking to Laurie Oakes." Melbourne Sun, January 6, 1977.

The Economist, "Snap Freeze, Might Not Last," April 16, 1977, p. 94.

"Interview with the Hon. E.G. Whitlam, Q.C., M.P." Monday Conference, broadcast live September 19, 1977, Australian Broadcasting Commission.

The Economist, "Poll While the Going's Good," October 29, 1977, pp. 89-90. 
The Economist, "Tough Fraser's Tough Budget," August 19, 1978, pp. $57-58$.

Gibson, Peter. "Fraser Backs Call: Freeze Pay for Six Months!" Daily Mirror, October 26, 1982, pp. 1-2.

Stutchbury, Michael. "Govt. Expects Freeze to Halve Inflation Rate." Australian Financial Review, December 17, 1982, p. 2.

Montgomery, Bruce. "Hawke Warns of 'Blunt Fiscal Instrument' If Unions Break Deal." The Australian, September 1, 1983, p. 1.

Greer, Wayne. "The Wages Bomb! Is It Ready to Explode Again?" Daily Mirror, September 8, 1983.

Editorial. "Keating's Smart Money Move." Sydney Morning Herald, January 30, 1985, p. 8.

Tingle, Laura. "Indirect Tax Cut, Wage Trade-Off the Keys to Lower Inflation." The Australian, August 24, 1988.

Interview with Bernie Fraser. Australian Financial Review (Decisions magazine supplement), October 18, 1990.

New Zealand

Evening Post, "Mr. Muldoon Questions Statement on Inflation," May 6, 1970.

Evening Post, "Inflation Rate Is 'Not out of the Ordinary," May 29, 1970.

Evening Post, "As Fight Goes on... Questions, Answers about NZ Inflation," July 21, 1970.

Evening Post, "Inflation Overseas Shows Need for Quick NZ Action," August 16, 1973.

New Zealand Herald, "Axe Aimed at Inflation," September 10, 1973, p. 1.

New Zealand Press Association. "P.M.'s Views on Fight against Inflation." Christchurch Press, September 10, 1973, p. 1.

Evening Post, "Mr. Muldoon 'Like an Ancient Prophet of Doom,' Says P.M.," December 3, 1974.

Parliamentary Reporter. "Underlying' Inflation Rate Down, Believes Mr. Muldoon." Evening Post, October 14, 1977.

Christchurch Press, "Inflation Now Running at 16.5 Per Cent-and It May Get Worse," January 14, 1980, p. 1.

Gooding, Bruce. "Not All the Answers, Says PM." Auckland Star, October 2, 1981. 
Muldoon, Robert. "Muldoon Says..." Evening Post, November 4, 1981.

Melchior, Philip. "P.M. Sees N.Z. Moving to 'Better Things."” Christchurch Press, January 13, 1982, pp. 1 and 6.

Wellington Business Reporter. "Inflation a Fight for Community." New Zealand Herald, February 13, 1982, sec. 2, p. 5.

Brash, Don. "Future Bleak without Consensus." Auckland Star, June 17, 1982.

Brash, Don. "Some Cheer, But a Real Surprise." Auckland Star, June 23, 1982, p. 2.

Wellington Bureau. "Our Midwinter Freeze." New Zealand Herald, June 23, 1982, p. 1.

Christchurch Press, "Mr. Muldoon Predicts Easing in Inflation Rate," December 28, 1982, p. 1.

Christchurch Press, "N.Z. Inflation Falls to Single Figure," July 11, 1983, p. 2.

Templeton, Ian. "Muldoon Flies in Face of Monetarists." Auckland Star, July 30, 1983, p. A4.

Christchurch Press, "Freeze Draws Interest," September 17, 1983, p. 25.

Evening Post, "Inflation Down to 5.4 p.c.," October 13, 1983.

Christchurch Press, "Inflation Rises to 4.7 p.c. on Consumer Index," July 10, 1984, p. 1.

Herbert, Patricia. "Sir Robert Forecasts Double-Digit Inflation." Christchurch Press, July 19, 1984, p. 3.

Christchurch Press, "Dramatic' Inflation Claim by Minister," August 3,1984, p. 4.

\section{References}

Bernanke, Ben S. 2004. "The Great Moderation." Remarks at the meetings of the Eastern Economic Association, Washington, DC, February 20.

Bernanke, Ben S., Thomas Laubach, Frederic S. Mishkin, and Adam S. Posen. 1999. Inflation Targeting: Lessons from the International Experience. Princeton, NJ: Princeton University Press.

Christiano, Lawrence J., and Christopher J. Gust. 2000. "The Expectations Trap Hypothesis." Federal Reserve Bank of Chicago Economic Perspectives 24 (2): 21-39. 
Debelle, Guy. 1996. "The Ends of Three Small Inflations: Australia, New Zealand and Canada." Canadian Public Policy 22 (1): $56-78$.

DeLong, J. Bradford. 1997. "America's Peacetime Inflation: the 1970s." In Reducing Inflation: Motivation and Strategy, ed. C. D. Romer and D. H. Romer, 247-76. Chicago: University of Chicago Press.

Department of Labour and National Service. 1970. "The Concept of Full Employment." In An Analysis of Full Employment in Australia, Labour Market Studies No. 2. Reprinted in Inflation and Unemployment, ed. J. W. Nevile and D. W. Stammer, 15-24. Ringwood, Victoria: Pelican, 1972.

Edwards, John. 1996. Keating: The Inside Story. Ringwood, Victoria: Viking Penguin.

Freeman, G. E. 1981. "A Central Banker's View of Targeting." In Monetary Targets, ed. B. Griffiths and G. E. Wood, 191-201. New York: St. Martin's Press.

Gruen, David, Adrian Pagan, and Christopher Thompson. 1999. "The Phillips Curve in Australia." Journal of Monetary Economics 44 (2): 223-58.

Gruen, David, and Glenn Stevens. 2000. "Australian Macroeconomic Performance and Policies in the 1990s." In The Australian Economy in the 1990s, ed. D. Gruen and S. Shrestha, 32-72. Sydney: Ambassador Press.

Guttmann, Simon. 2004. The Rise and Fall of Monetary Targeting in Australia. Kew, Victoria: Australian Scholarly Publishing.

Ireland, Peter N. 1999. "Does the Time-Consistency Problem Explain the Behavior of Inflation in the United States?" Journal of Monetary Economics 44 (2): 279-91.

Kelly, Paul. 1992. The End of Certainty: Australia in the 1980s. Sydney: Allen and Unwin.

Laidler, David. 1978. "Review: Towards Full Employment and Price Stability." Journal of Economic Literature 16 (3): 1040-44.

McCracken, Paul, et al. 1977. Towards Full Employment and Price Stability: A Report to the OECD by a Group of Independent Experts. Paris: Organisation for Economic Co-Operation and Development.

Nelson, Edward. 2004. "The Great Inflation of the Seventies: What Really Happened?" Federal Reserve Bank of St. Louis Working Paper 2004-001. 
Nelson, Edward, and Kalin Nikolov. 2004. "Monetary Policy and Stagflation in the United Kingdom." Journal of Money, Credit, and Banking 36 (3): 293-318.

Nevile, J. W. 1981. "Definitions and Measurements of the Australian Budget Deficit." In Policies Against Stagflation, ed. J. W. Nevile, 37-52. Melbourne: Longman Cheshire.

Orden, David, and Lance A. Fisher. 1993. "Financial Deregulation and the Dynamics of Money, Prices, and Output in New Zealand and Australia." Journal of Money, Credit, andBanking 25 (2): $273-92$.

Organisation for Economic Co-Operation and Development. 1973. The Measurement of Domestic Cyclical Fluctuations. Paris: Organisation for Economic Co-Operation and Development.

Orphanides, Athanasios. 2003. "The Quest for Prosperity without Inflation." Journal of Monetary Economics 50 (3): 633-63.

Romer, Christina D., and David H. Romer. 2002. "The Evolution of Economic Understanding and Postwar Stabilization Policy." In Rethinking Stabilization Policy, 11-78. Kansas City, MO: Federal Reserve Bank of Kansas City.

Sargent, Thomas J. 1999. The Conquest of American Inflation. Princeton, NJ: Princeton University Press.

Taylor, John B. 1993. "Discretion versus Policy Rules in Practice." Carnegie-Rochester Conference Series on Public Policy 39 (1): $195-214$.

Taylor, John B. 1997. "America's Peacetime Inflation: The 1970s: Comment." In Reducing Inflation: Motivation and Strategy, ed. C. D. Romer and D. H. Romer, 276-80. Chicago: University of Chicago Press.

Woodford, Michael. 2003. Interest and Prices: Foundations of a Theory of Monetary Policy. Princeton, NJ: Princeton University Press. 